\title{
Growth, Total Production and Feed Efficiency of Catfish (Clarias sp.) Orally Administered with Shrimp Waste Hydrolyzate
}

\author{
Dimas Rizky Hariyadi $^{1}$, Alim Isnansetyo ${ }^{2 *}$, Indah Istiqomah $^{2}$, Ign. Hardaningsih ${ }^{2}$, Wahyudi ${ }^{3}$ \\ and Sung Sam Kim ${ }^{3}$ \\ ${ }^{I}$ Post Graduate Program of Fisheries Sciences, Universitas Gadjah Mada, Indonesia \\ ${ }^{2}$ Department of Fisheries, Faculty of Agriculture, Universitas Gadjah Mada, Jl. Flora, Bulaksumur, Yogyakarta \\ ${ }^{3}$ CJ Cheil Jedang Feed Semarang, Indonesia \\ ${ }^{*}$ Corresponding author: isnansetyo@ugm.ac.id
}

Received: 02 February 2018; Accepted: 12 Mei 2018

\begin{abstract}
Dimas Rizky Hariyadi, Alim Isnansetyo, Indah Istiqomah, Ign. Hardaningsih, Wahyudi and Sung Sam Kim. 2018. Growth, Total Production and Feed Efficiency of Catfish (Clarias sp.) Orally Administered with Shrimp Waste Hydrolyzate. Aquacultura Indonesiana, 19 (1): 15-20. Shrimp Waste Hydrolyzate (SWH) /Shrimp Soluble Extract (SSE) is a product produced from the enzymatic process of shrimp waste. SWH contains essential and non-essential amino acids which useful for fish. This study aimed to determine effect of SWH on the growth and total production of catfish. The parameters observed were average growth rate, specific growth rate (SGR), food conversion ratio (FCR), protein efficiency ratio (PER), total production and length weight relationship from beginning until the end of rearing period. Growth performance was observed by calculating average growth rate and SGR of catfish. The results of this study showed that oral administration of SWH significantly increased SGR of catfish length at $4^{\text {th }}$ sampling period with value $1.54 \%$ body length/day. Administration of SWH did not affect on the AGR, FCR, PER and total production. The growth pattern of catfish is negative allometric.
\end{abstract}

Keywords: Catfish; Food conversion ratio; Growth; Production; Protein efficiency ratio; Shrimp waste hydrolyzate

\section{Introduction}

Catfish is one of the most popular freshwater aquaculture species in Indonesia. Productions of catfish reached second ranks after tilapia production in 2015 , with a total production of 719,619 tons, from the target of $1,058,400$ tons (KKP, 2016). The data indicate that the target of catfish production has not been achieved. In aquaculture, feed is a key role to increasing production. Improved nutritional value in feed may provide better growth. Utilization of nutrients in an efficient diet is an important factor to improve the growth.

Protein plays a key role in maintaining optimal growth and reproduction of fish (Martínez-Palacios et al., 2007; Deng et al., 2011). Deficiency of amino acids can lead to a decrease in growth (NRC, 1983). Shrimp waste hydrolyzate (SWH)/Shrimp Soluble Extract (SSE) is a product of protein hydrolyzate produced from shrimp head waste and has been enriched with amino acid and peptide mixtures. SWH as an attracting agent has activated amino acids and active peptides that are highly digestible and can be absorbed for animals (Gildberg and Stenberg 2001; Aksnes et al., 2006). $\mathrm{SWH}$ of $2 \%$ mixed into feeds give higher growth performance in rainbow trout (Jo et al., 2014) and has a beneficial effect on growth performance in Malabar grouper (Epinephelus malabaricus) (Li et al., 2009) and red sea bream (Pagrus major) (Khosravi et al., 2015). However, there is a lack of information regarding to the supplementation of $\mathrm{SWH}$ in feed of freshwater aquaculture species. Publications on the evaluation of SWH to promote catfish growth and to improve feed efficiency are not available. This study aimed to evaluate SWH in increasing growth performance and total production of catfish (Clarias sp.).

\section{Materials and Methods}

\section{Experimental setup}

Nine fiber glass containers $(50 \mathrm{~cm} \times 50$ $\mathrm{cm} \times 60 \mathrm{~cm}$ ) were used for rearing catfish at density of $40 \mathrm{fish} / \mathrm{container}$. The containers were filled with clean water until $40 \mathrm{~cm}$. Catfish with $9.0 \pm 0.2 \mathrm{~g}$ of individual weight was reared for 90 days. Feed treatments were given continuously until the observation done.

\section{Experimental Design}

This study used a completely randomized design (CRD) with three treatments in triplicates, 
P1 (commercial feed, as negative control), P2 (feed $+2 \% \mathrm{SWH}$ ) and $\mathrm{P} 3$ (feed $+2 \%$ OL4, as positive control). OL4 is a commercially available immunostimulant. The observation of catfish growth included measurement of length and weight were performed periodically. Total production was calculated at the end of the rearing period.

\section{Feed and Feeding}

Catfish used in this study was provided from a catfish hatchery in Bantul, Yogyakarta. Catfish was fed twice a day at 08.00 and 15.00 . The feed was a commercial pellet from Cheil Jedang feed manufacture (Galaxy GL-2) with 20-25\% of protein content. SWH (Vietnam Organic, Ca Mau Vietnam) was weighed and then dissolved in $40 \mathrm{~mL}$ of aquadest and sprayed to the feed. Control feed was the commercial feed without any supplement. After being sprayed, the feed was dried at room temperature $\left(20-25^{\circ} \mathrm{C}\right)$ overnight before being applied to the fish.

\section{Sample Collection and Analysis}

\section{Average body weight and length}

Catfish was weighed using scales with a $0.01 \mathrm{~g}$ precision level. Total length measurement was performed by measuring the catfish using a $30 \mathrm{~cm}$ ruler with a $0.1 \mathrm{~cm}$ precision level. The length and weight data were collected every two weeks from beginning until the end of cultivation.

\section{Specific growths of length and weight}

Specific growths of length and weight were calculated every two weeks by formula (Zonneveld et al., 1991):

$$
\begin{aligned}
& \mathrm{SGR}=\frac{\ln \mathrm{Lt}-\ln \mathrm{Lo}}{\mathrm{t}} \times 100 \% \\
& \mathrm{SGR}=\frac{\ln \mathrm{Wt}-\ln \mathrm{Wo}}{\mathrm{t}} \times 100 \%
\end{aligned}
$$

Explanation:

SGR : specific growth rate $(\%)$

$\mathrm{t}$ : time (day)

Lt : length of fish at the end of rearing $(\mathrm{g})$

L0 : length of fish at the beginning of rearing $(\mathrm{g})$

Wt : weight of fish at the end of rearing $(\mathrm{g})$

W0 : weight of fish at the beginning of rearing $(\mathrm{g})$

\section{Size distribution}

Size distribution was observed at the end of cultivation period and classified in three sizes: small size (50-100 g), normal size (100-150 g) and big size $(>150 \mathrm{~g})$. Size distribution of catfish showed in percentage $(\%)$.

\section{Feed conversion ratio}

Feed conversion ratio was calculated by calculating the amount of feed given during the cultivation, compared to the increase of biomass during cultivation period, FCR calculated by the formula of Stickney (1979) as follows:

Explanation:

$$
\mathrm{FCR}=\frac{\sum \text { Feed }}{\mathrm{Wt}-\mathrm{Wo}}
$$

FCR : feed conversion ratio

$\Sigma$ Feed : the consumed feed during rearing $(\mathrm{g})$

Wt : weight of fish at the end of the rearing $(\mathrm{g})$

W0 : weight of fish at the beginning of rearing $(\mathrm{g})$

\section{Protein efficiency ratio}

Calculation of protein efficiency ratio using the formula of Zonneveld et al. (1991):

$$
\mathrm{SGR}=\frac{\mathrm{Wt}-\mathrm{Wo}}{\mathrm{Pi}} \times 100 \%
$$

Explanation:

PER : protein efficiency ratio $(\%)$

Wt : weight of fish at the end of rearing $(\mathrm{g})$

W0 : weight of fish at the beginning of rearing $(\mathrm{g})$

$\mathrm{Pi} \quad$ : the weight of the feed protein consumed $(\mathrm{g})$

\section{Total production}

The biomass of catfish in each container measured at the end of rearing period (90 days) by using scale with a $1 \mathrm{~g}$ precision level to obtain the total production data.

\section{Length weight relationship}

Analysis of $60 \mathrm{fish} /$ treatments length and weight relationship using regression test with formula (Effendie, 1979):

Explanation:

$$
\mathrm{W}=\mathrm{aL}^{\mathrm{b}}
$$

W : fish body weight (g)

$\mathrm{L} \quad$ : fish length $(\mathrm{cm})$

$\mathrm{a}$ and $\mathrm{b}$ : constants

\section{Data Analysis}

The growth performance, FCR, PER and total production data were analyzed by using One-way analysis of variance through SPSS 20.0 program from IBM Corporation, New York USA. Normality and homogeneity tests were performed before the variance test. Duncan's test was performed on a treatment that showed significant difference $(\mathrm{P} \leq 0.05)$ to know significance between treatments with $95 \%$ confidence level. 


\section{Results}

The growth of length and weight increased in each sampling period. The variance analysis of the specific growth rates of weight and length showed that there was significant difference $(P>0.05)$ between P3 (positive control) with other treatments (P1 and P2) at $6^{\text {th }}$ sampling period (70 days). The highest growth of weight and length were found in P3. Average growth rate of length and weight of catfish in this study are presented in Figure 1.

Specific growth rates of length and weight in this study decreased by increasing the rearing period. The variance analysis of the specific growth rate of weight showed that there was no significant difference $(\mathrm{P}>0.05)$. P2 $\quad(\mathrm{SWH}$ treatment) significantly increased $(\mathrm{P} \leq 0.05)$ specific growth rates of length at $4^{\text {th }}$ sampling period (42 to 56 days) with value of $1.2 ; 1.54$ and 0.82 , respectively. Specific growth rate of length and weight of catfish are presented in Figure 2.

Size distribution analysis in this study indicated that P2 (SWH treatment) provided a highest portion of small size $(50-100 \mathrm{~g})$ and normal size (100-150 g) groups with percentages of $29.91 \%$ and $37.19 \%$, respectively. However, P2 showed lowest percentage in big size (>150 g) group. Highest portion of big size group was found in P3 (positive control) treatment with a percentage of $59.69 \%$. Size distribution of catfish in this study is presented in Table 1 .

The variance analysis of feed conversion ratio in this study showed no significant difference $(\mathrm{P}>0.05)$. P2 showed the highest level of feed conversion ratio, 1.51. The value of FCR in this study is presented in Table 2 .

The variance analysis of protein efficiency ratio in this study showed significant difference $(\mathrm{P} \leq 0.05)$ between $\mathrm{SWH}$ treatment $(\mathrm{P} 2)$ with positive and negative control. P2 showed the lowest level of protein efficiency ratio with value $1.89 \%$. The PER in this study is presented in Table 3.

The variance analysis of total production, biomass improvement and length improvement showed a significant difference $(\mathrm{P} \leq 0.05)$ between P3 (positive control) with P1 (negative control) and P2 (feed with 2\% HLU). P3 resulted the highest total production, biomass improvement and length improvement namely 4,478.97 g; $4132.21 \mathrm{~g}$ and $16.61 \mathrm{~cm}$, respectively.

The result of length and weight relationship test showed that the growth pattern of catfish in each treatment was negative allometric $(b<3)$. The value of "a" ranged from 0.009 to 0.015 , and the value of " $b$ " ranged from 2.76 to 2.91 . The relationship of length and weight is presented in Table 5.

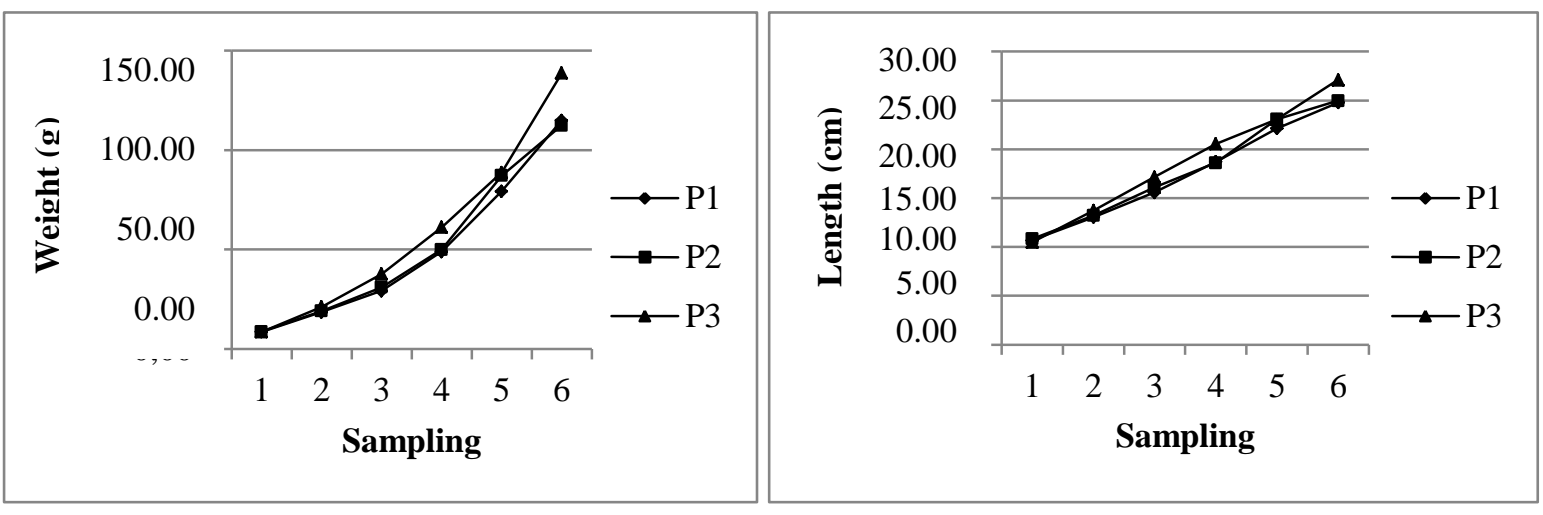

Figure 1.Weight and length increament of catfish fed with 2\% SWH and OL4 in all of sampling period.
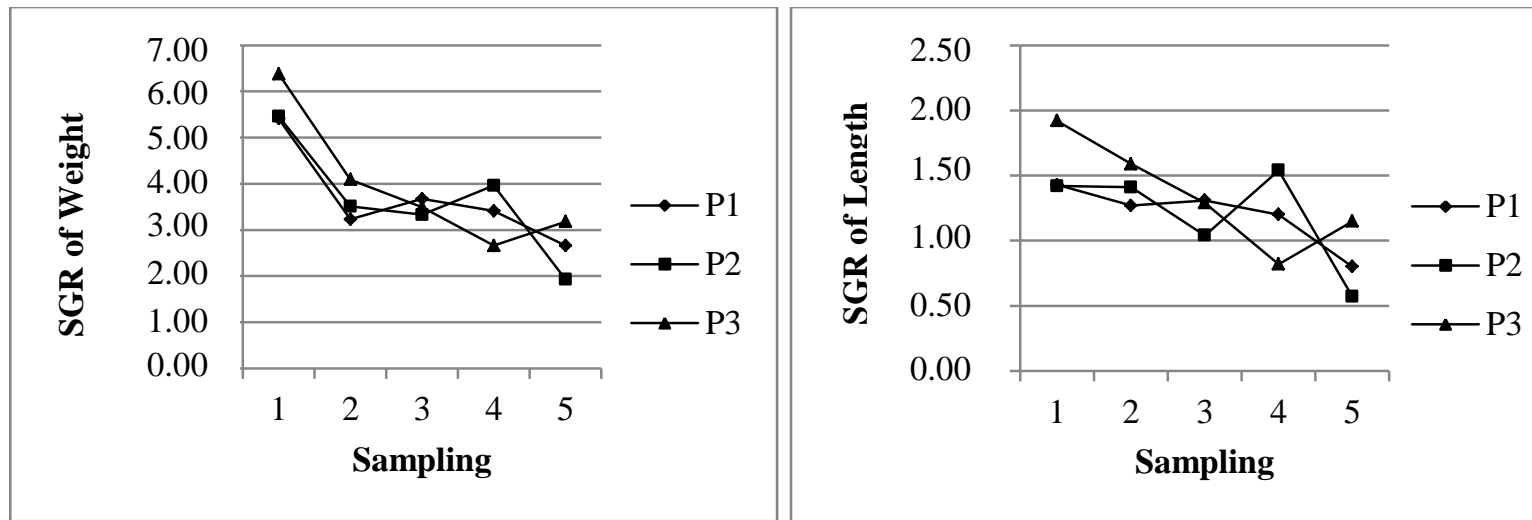

Figure 2. Specific growth rate of catfish fed with $2 \%$ SWH and OL4 in all of sampling period. 
Table 1 . Size distribution of catfish fed with $2 \%$ SWH and OL4

\begin{tabular}{lccc}
\hline \multirow{2}{*}{ Treatment } & \multicolumn{3}{c}{ Size Distribution $\mathbf{( \% )}$} \\
\cline { 2 - 4 } & $\mathbf{5 0 - 1 0 0 ~} \mathbf{~ c m}$ & $\mathbf{1 0 0}-\mathbf{1 5 0} \mathbf{~ c m}$ & $\mathbf{1 5 0} \mathbf{~ c m}$ \\
\hline P1 (negative control) & 25.42 & 36.96 & 37.62 \\
P2 (SWH 2\%) & 29.91 & 37.19 & 32.90 \\
P3 (positive control) & 8.41 & 34.90 & 56.69 \\
\hline
\end{tabular}

Table 2. Food convertion ratio of catfish fed with $2 \%$ SWH and OL4

\begin{tabular}{lc}
\multicolumn{1}{c}{ Treatment } & FCR \\
\hline P1 (negative control) & $1.20 \pm 0.13$ \\
P2 (SWH 2\%) & $1.51 \pm 0.27$ \\
P3 (positive control) & $1.15 \pm 0.04$ \\
\hline
\end{tabular}

Table 3. Protein efficiency ratio of catfish fed with $2 \%$ SWH and OL4

\begin{tabular}{ll}
\hline \multicolumn{1}{c}{ Treatment } & PER (\%) \\
\hline P1 (negative control) & $2.43 \pm 0.29^{\mathrm{b}}$ \\
P2 (SWH 2\%) & $1.89 \pm 0.34^{\mathrm{a}}$ \\
P3 (positive control) & $2.46 \pm 0.08^{\mathrm{b}}$ \\
\hline
\end{tabular}

Table 4. Biomass and length improvement, and total production of catfish fed with $2 \%$ SWH

\begin{tabular}{lccc}
\hline \multicolumn{1}{c}{ Treatment } & $\begin{array}{c}\text { Biomass } \\
\text { Improvement (g) }\end{array}$ & $\begin{array}{c}\text { Length } \\
\text { Improvement }(\mathbf{c m})\end{array}$ & Total Production (g) \\
\hline P1 (negative control) & $3050.85 \pm 258.81^{\mathrm{a}}$ & $14.09 \pm 0.84^{\mathrm{a}}$ & $3,399.59 \pm 257.16^{\mathrm{a}}$ \\
P2 (SWH 2\%) & $3165.46 \pm 242.79^{\mathrm{a}}$ & $14.15 \pm 1.19^{\mathrm{a}}$ & $3,517.66 \pm 248.19^{\mathrm{a}}$ \\
P3 (positive control) & $4132.21 \pm 362.28^{\mathrm{b}}$ & $16.61 \pm 0.59^{\mathrm{b}}$ & $4,478.97 \pm 364.96^{\mathrm{b}}$ \\
\hline
\end{tabular}

*The same superscript letter in the same column indicates no significant difference $(\mathrm{P}>0.05)$

Table 5. Length weight relationship of catfish orally administered with SWH

\begin{tabular}{llll}
\multicolumn{1}{c}{ Treatment } & \multicolumn{1}{c}{$\mathbf{W}=\mathbf{a L}^{\mathbf{b}}$} & Growth Pattern & $\mathbf{R}^{\mathbf{2}}$ \\
\hline P1 (negative control) & $\mathrm{W}=0.0113 \mathrm{~L}^{2.86}$ & Negative Allometric & 0.89 \\
P2 (SWH 2\%) & $\mathrm{W}=0.0150 \mathrm{~L}^{2.76}$ & Negative Allometric & 0.87 \\
P3 (positive control) & $\mathrm{W}=0.0090 \mathrm{~L}^{2.91}$ & Negative Allometric & 0.70 \\
\hline
\end{tabular}

\section{Discussion}

The results of the variance analysis showed that SWH did not provide a significant improvement $(\mathrm{P}>0.05)$ in average body weight and length, but the increments were still in optimum range for catfish culture for 90 days. This result is similar to the results obtained by Hung (2014), used SWH/SSE has no significant effect on growth of tilapia. Suprayudi et al. (2006) found that the addition of commercial yeast, $\beta$-glucan, vitamin $\mathrm{C}$ and chromium-yeast in the formulation of artificial feed also does not significantly affect the nutritional value and growth of grouper (Cromileptes altivelis). Other studies reported that feeding with different protein and protein energy levels has an effect on feed efficiency, but does not affect relative growth rates in carp (Cyprinus carpio) (Setiawati et al., 2008). Specific growth rate of catfish length in this study increased at $4^{\text {th }}$ sampling period indicating it's effected on SGR of catfish length.

All of treatments in this study produced big size category of catfish $(>150 \mathrm{~g})$ in the range of $37.62-56.69 \%$. P3 (positive control) resulted in the highest percentage of this portion. In contrast, this treatment also resulted in the lowest percentage of small size catfish indicating the good distribution of size dominated by big size and medium size group. Variation in size was found in $\mathrm{P} 1$ and $\mathrm{P} 2$ indicated that $\mathrm{P} 3$ is the superior treatment to promote the growth of catfish.

The feed conversion ratio (FCR) indicates the level of feed efficiency for biomass increment. The lower feed conversion indicates higher feed efficiency to support the growth of fish. The FCR in this study was not significant different $(\mathrm{P}>0.05)$ among treatments. Feed conversion ratio is not an absolute number, since it is not only determined by the quality of feed, but also influenced by other factors such as fish species and fish size, stocking density, water quality and genetic factors (Akbar et al., 2008). Feed quality is influenced by the digestibility or absorption level of feed nutrient. The lower feed conversion ratio indicates the better feed quality (Djariah, 2005).

Increase in protein levels will not certainly improve feed efficiency. The average feed efficiency increases by increasing protein feed 
rate, but decreases in the feed with the excessive protein level. The reduced feed efficiency may be caused by excess protein, so protein digestion rate is not optimal. If the protein is excessive in feed, the fish consumes excessive protein, so the protein is not used for growth but will be disposed as ammonia (Lan and Pan, 1993). Protein efficiency ratios are used to determine the quality of proteins in feed (Handajani and Widodo, 2010). The PER of SWH treatment in this study was significant lower than that of positive and negative control treatments. This result indicated that protein content in P1 and P3 is more appropriate for catfish requirement. Consequently the use of protein for growth is higher. According to a study conducted by Bhilave et al. (2012), compositions of feed formulation affect the value of protein efficiency ratios. The value of protein efficiency in feed is also influenced by several factors included fish size and fish feeding rate.

The result of variance analysis showed that there was significant difference $(\mathrm{P} \leq 0.05)$ of total production, biomass and length improvements between positive control (P3), SWH treatment (P2) and negative control (P1). P2 showed higher levels in these three parameters compared to P1, but exhibited lower levels than that of positive control (P3). These results indicated that the commercial product (P3) gives more effective impact than SWH in improving total production, biomass and length improvements of catfish. This product able to increase the growth of fish because the high concentration of available amino acids produce from tuna fish.

The catfish growth in all treatments was in an allometric negative $(b<3)$ pattern, so it can be stated that the growth of catfish weight is slower compared to its length growth. Length and weight of catfish in this study is correlated because it has a value of $\mathrm{R}$ close to 1 (one), it shows that the relationship between the length and weight of the fish is very close. The growth pattern is determined based on the value of " $b$ " obtained from the equation of long and weight relationship of catfish. The values of " $b$ " in this study were different among the treatments, but the treatments still have the same growth pattern. Differences of "b" value are caused by biological and ecological factors (Manik, 2009). In wild ecosystem, ecological factors affecting the " $b$ " value are seasons, water quality and geographical position (Jennings et al., 2001). Biologically the ' $b$ " value is influenced by growth phase, gender, gonadal development and feeding habits (Froese, 2006; Tarkan et al., 2006).

\section{Conclusion}

This study showed that oral administration of shrimp waste hydrolyzate (SWH) significantly increased $(\mathrm{P} \leq 0.05)$ specific growth rates of length at $4^{\text {th }}$ sampling period (42 to 56 days). SWH did not affect on the AGR, FCR, PER and total production of catfish.

\section{Acknowledgement}

Part of this study was financially supported by Cheil Jedang Coorporation. The authors would like to express the appreciation to those who helped support this research at Aquaculture Research Station, Departement of Fisheries, Universitas Gadjah Mada, Yogyakarta.

\section{References}

Akbar, J. and A. Nur. 2008. Optimalisasi Perikanan Budidaya Rawa Dengan Pakan Buatan Alternatif Berbasis Bahan Baku Lokal. Program I-MHERE B.1 Bacth II Lambung Mangkurat University.

Aksnes, A., B. Hope, E. Jönsson, B.T. Björnsson and S. Albrektsen. 2006. Size-fractionated fish hydrolysate as feed ingredient for rainbow trout (Oncorhynchus mykiss) fed high plant protein diets. In: growth, growth regulation and feed utilization. Aquaculture, 261: 305-317.

Bhilave, M.P., S. Bhosale and B. Nadaf. 2012. Protein efficiency ratio (PER) of Ctenopharenge donidella fed on soybean formulated feed. Biological Forum-An International Journal, 4(1): 79-81.

Deng, D.F., Z.Y. Ju, W. Dominy, R. Murashige and R.P. Wilson. 2011. Optimal dietary protein levels for juvenile pacific thread fin (Polydactyluss exfilis) fed diets with two levels of lipid. Aquaculture, 316: 25-30.

Djariah, A.S. 2005. Budidaya Ikan Patin. Kanisius, Yogyakarta. $87 \mathrm{p}$.

Effendie, M.I. 1979. Metode Biologi Perikanan. Yayasan Dewi Sri, Bogor, $112 \mathrm{p}$.

Froese, R. 2006. Cube Law, condition factor and weight length relationship: history, metaanalysis and recommendations. Journal of Applied Ichthyology, 22: 241-253.

Gildberg, A. and E. Stenberg. 2001. A new process for advanced utilization of shrimp waste. Process Biochemistry, 36: 809-812.

Handajani, H. and W. Widodo. 2010. Nutrisi ikan. UMM Press, Malang, $270 \mathrm{p}$. 
Hung, L.T. 2014. Shrimp soluble extract-novel feed attractant for aquaculture. Global Aquaculture Advocate, 17: 81-82.

Jennings, S., M.J. Kaiser and J.D. Reynolds. 2001. Marine Fishery Ecology. Blackwell Sciences, Oxford, $432 \mathrm{p}$.

Jo, H., H. Yun, M. Moniruzzaman and S.C. Bai. 2016. Evaluation of dietary fishmeal analogue with addition of shrimp soluble extract on growth and nonspecific immune response of rainbow troat (Oncorhynchus mykiss). Journal of World Aquaculture Society, DOI: 10.1111/jwas.12355.

Kementerian Kelautan dan Perikanan Republik Indonesia. 2016. Laporan Kinerja. Direktorat Jenderal Perikanan Budidaya, 84 pp.

Khosravi, S., S. Rahimnejad, M. Herault, V. Fournier, C.R. Lee, H.TD. Bui and K.J. Lee. 2015. Effects of protein hydrolyzates supplementation in low fish meal diets on growth performance, innate immunity and disease resistance of red sea bream Pagrus major. Fish and Shellfish Immunology, 45: 858-868.

Lan, C.C. and B.S. Pan. 1993. Invitro ability stimulating the proteolysis of feed protein in the midgut gland of Grass shrimp (Pennaeus monodon). J. Aquaculture, 109: 59-70.

Li, P., K. Mai, J. Trushenski and G. Wu. 2009. New developments in fish amino acid nutrition: towards functional and environmentally oriented aquafeeds. Amino Acids, 37(1): 43-53.

Manik, N. 2009. Hubungan panjang-berat dan faktor kondisi ikan layang (Decapterus ruselli) dari perairan sekitar Teluk Likupang Sulawesi Utara. Jurnal Ilmiah Oseanologi dan Limnologi, 35(1): 65-74.

Martínez-Palacios, C.A., M.G. Ríos-Durán, L. Ambriz-Cervantes, K.J. Jauncey and L.G. Ross. 2007. Dietary protein requirement of juvenile Mexican silverside (Menidiaestor Jordan 1879), a stomachless zooplanktophagous fish. Aquac. Nutr., 13: 304-310.

NRC (National Research Council). 1983. Nutrient Requirement of Warmwater Fishes and Shellfishes. Revised Edition. National Academy of Sciences, Washington D.C, $102 \mathrm{p}$.

Setiawati, M., R. Sutajaya and M.A. Suprayudi. 2008. Effect of different protein and protein-energy ratio in diet on growth of common carp (Cyprinus carpio) fingerling. Jurnal Akuakultur Indonesia, 7(2): 171178.

Stickney, R.R. 1979. Principle of Warm Aquaculture. John Willey and Sons, New York, 375 p.

Suprayudi, M.A., L. Indriastuti and M. Setiawati. 2006. Effect of enriched feed by immunostimulant on immune response and growth of humpback grouper (Cromileptes altivelis). Jurnal Akuakultur Indonesia, 5(1): 77-86.

Tarkan, A.S., O. Gaygusuz, P. Acipinar, C. Gursoy and M. Ozulug. 2006. Length-weight relationship of fishes from the Marmara Region (NW-Turkey). Journal of Applied Ichthyology, 22(4): 271-273.

Zonneveld, N., E.A. Huisman and J.H. Boon. 1991. Aquaculture Principles. Gramedia Pustaka Utama, Jakarta, 318 p. 